\title{
Into the Grey Zone, Or: How to Track Fading Multiculturalism in Southeastern Europe
}

\author{
The Exhibition "“We Live Word to Word." \\ Banat - Transylvania - Bukovina. Ethnograffiti of Southeastern Europe' \\ at the Friedrich Schiller University Jena, 2018-2020
}

\begin{abstract}
The exhibition "“We Live Word to Word." Banat - Transylvania - Bukovina. Ethnograffiti of Southeastern Europe' resulted from an interdisciplinary project seminar at the Friedrich Schiller University Jena, based on a team ethnographic journey to Romania and Ukraine. Participants in the seminar, initiated in 2018, investigated how communities and togetherness have been constructed in multiethnic societies. The purpose was to find out what has remained of the region's multicultural nature after the political changes of 1989. The team made their own observations, recorded interviews, and took notes, the resulting fragments of cultural diversity being later pieced together in the exhibition. Some contributions were colourful-even garish-while others were tender and withdrawn. Combined and linked, the final result seemed like a fleeting picture such as might have been sprayed from the aerosols of a street-artist-a sort of 'ethnograffiti'. In this article, the authors reflect on how the exhibition was put together.
\end{abstract}

Valeska Bopp-Filimonov is a Junior Professor at the Department for Romance Studies at the Friedrich Schiller University in Jena.

Anne Dippel is a Research Assistant at the Department for Cultural Anthropology and Cultural History at the Friedrich Schiller University in Jena.

\section{On Language as a Dwelling and Inclusive Cultural Identities}

Wir wohnen Wort an Wort ('We live word to word') is the title of a poem written by Rose Ausländer. In Ausländer's work language propagates a very particular sound nourished by the vibrant intellectual scene of Chernivtsi / Cernăuți / Czernowitz, her hometown. The phrase Wir wohnen Wort an Wort is difficult to translate for the correct sense but it points to a language-scape in which people of different tongues live and speak 'door to door'. Each word is 

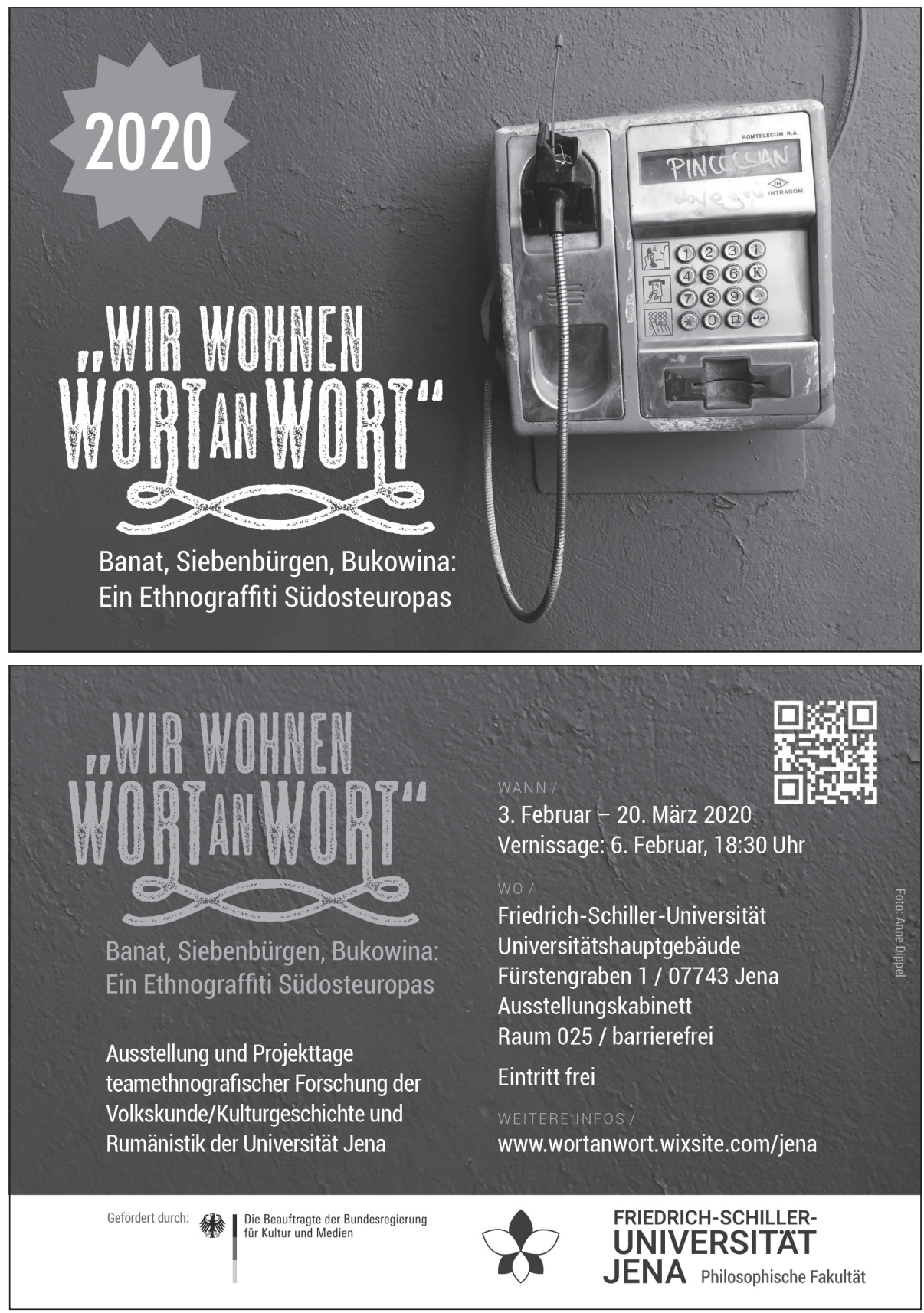

Image 1: Postcard with Information about the Exhibition (Courtesy: Anne Dippel/ Britta Kussin) 
like the front door of a house, one that is a home but at the same time a border to another word which is the front door to another house. When we initiated an interdisciplinary seminar with students at the Friedrich Schiller University in Jena in 2018, we took Ausländer's image as our starting point. The final result of our project is the exhibition "'We Live Word to Word." Banat Transylvania - Bukovina. Ethnograffiti of Southeastern Europe' ('Wir wohnen Wort an Wort'. Banat-Siebenbürgen-Bukowina. Ein Ethnograffiti Südosteuropas). It was shown at Jena University in April and May 2019, and will be renewed at the same location once more from 3 February to 20 March 2020. An online version will be inaugurated during the course of the year. ${ }^{1}$

That single line by Ausländer aptly sums up our anthropological insights into the formerly multicultural world encompassing Bukovina, Transylvania and Banat gathered during our excursion to Romania and Ukraine. Our two week journey began in Timișoara / Temeswar, the cultural and economic capital of the Romanian part of the historic Banat region, where we arrived by train from Jena via Budapest. From there, we hired two minibuses which took us to Nițchidorf / Nitzkydorf, Sibiu/Hermannstadt, Brașov/Kronstadt, Alțâna / Alzen, Sighișoara / Schäßburg, Biertan/Birthälm, Mediaș / Mediasch and finally Cluj/Klausenburg in the heart of Transylvania. The night train brought us from Cluj to Suceava in the Romanian region of Moldova, from where we continued our journey on the bus to Chernivtsi / Cernăuți / Czernowitz in Ukraine. There, colleagues of the University Alexandru Ioan Cuza of Iași / Jassy met us with their university vehicle to bring us back to Romania, to Iași, where we were their guests. At the end of our stay we flew home to Germany.

The preparatory work for the journey was greatly varied. The project began with Anne Dippel's cultural anthropological seminar called 'Transylvania, Banat, Bukovina. An Ethnographic Journey to the Sinking Continent of German Language'. The guiding question was whether contemporary German society could learn anything by looking at Germans whose identity, entangled as it was in a multicultural web, had always been 'minor'. ${ }^{2}$ The seminar took place during the summer term of 2018 and after newly appointed professor of Romanian Studies Valeska Bopp-Filimonov joined in, we broadened the perspective, made a close study of the recent history of the region and included a closer look at the Romanians' image of themselves. The basic question however remained: How could the contemporary German society develop an inclusive concept of a multiethnic and multicultural German identity? A soci-

\footnotetext{
${ }^{1}$ For the time being, cf. the project's website at https://wortanwort.wixsite.com/jena. All internet sources were accessed on 2 January 2020.

${ }^{2}$ Cf. Gilles Deleuze/Félix Guattari, Kafka. Toward a Minor Literature, Minneapolis, London 1986.
} 
ety where people live side by side with diverse others and who hear diverse 'words', coming from all over the world in today's globalized times?

During that academic year's first term, we also worked together to plan and organize our field trip. Working in small groups, the students became a vital part of that process, and even did some of the administrative work connected with fund-raising. We all decided what paths we would tread and how we should travel, whether by rail, by air, using motor vehicles, or on foot. Our journey into a region which has known various visions of what 'German' has meant in both past and present, was designed to create a multilevel training ground, in more than just empirical methods, philological hermeneutics, and public anthropology. In preparation we studied the culture and history of the region, and all sorts of written material supported and guided us in designing and then undertaking our trip. The students read poems, novels and fragments by such writers as Adolf Joseph Storfer, Paul Celan, Oskar Pastior, Herta Müller and Rose Ausländer, and used what they learned to approach past and present perceptions of German and Jewish culture. They immersed themselves in the experience of the multiethnic fabric of Southeastern Europe, which is a region with a particularly high density of different languages, cultures, and customs. ${ }^{3}$

In the winter term of 2018, we jointly led the post-excursion seminar and, together with the students, we sorted and analysed the data collected during the field trip and turned the findings into a multimedia project for the wider public. This consisted of an exhibition and events which were to take place in the spring and summer of 2019 in various locations in Jena, and included lectures, discussions, and a theatre piece. The project members documented and eventually showcased how their interlocutors had perceived multicultural cohabitation in both the past and present. The students included their reflections on the interdisciplinary set-up of our seminar and gave certain technical details of our collaborative efforts. In the short time available it proved to be a challenge not only to gain properly deep insights, but also to find a way to present our findings in an exhibition that would capture and map everything we had discovered.

\footnotetext{
${ }^{3}$ Adolf Josef Storfer, Wörter und ihre Schicksale, Berlin 2000 (orig. 1935); Adolf Josef Storfer, Im Dickicht der Sprache, Berlin 2000 (orig. 1937); Adolf Josef Storfer, Die Gelbe Post. Eine Emigrantenzeitschrift, Vienna 1999 (orig. 1939); Paul Celan, Die Gedichte. Kommentierte Gesamtausgabe in einem Band. Ed. by Barbara Wiedemann, Frankfurt/M. 2003; Oskar Pastior, Werkausgabe in vier Bänden, Munich 2003-2008, esp. vol. 3: 'Minze Minze, flaumiran Schpektrum' (2004); Herta Müller, Die Nacht ist aus Tinte gemacht. Herta Müller erzählt ihre Kindheit im Banat, 2 audio discs, Wyk auf Föhr 2009; Herta Müller, Atemschaukel, Munich 2009; Rose Ausländer, Phönixzeit. Ausgewählte Gedichte/ Час фенікса. Вибрані вірші, Czernowitz 1998, http://shron1.chtyvo.org.ua/Auslender_Roza/Chas_ feniksa_Vybrani_virshi_ukrnim.pdf.
} 


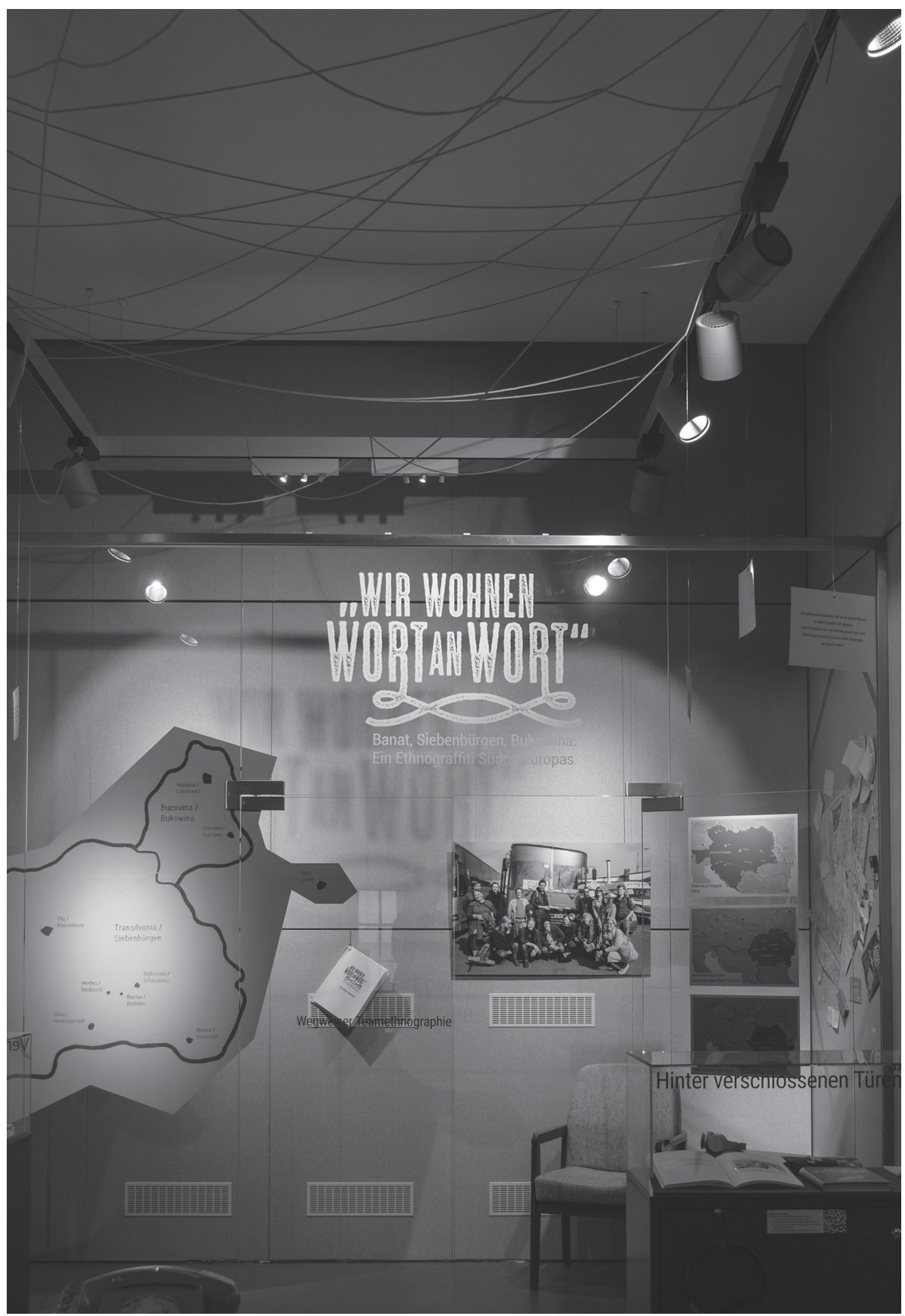

Image 2: Part of the Exhibition Room (Courtesy: Lukas Davids) 
We displayed our impressions of intercultural common sense in the regions we visited, although we were careful to frame them accurately in their historical context. We included a reflection of our research process, but in the end we had had many helping hands and had managed too to obtain substantial financial support to realize our goals. All in all we had received nearly 30,000 euros, these days a large amount for the Humanities in Germany. The project was realized thanks to the support of the Cultural Advisors for Transylvania and the Danube Region at the Commissioner for Culture and Media of the Federal Government of Germany, the Theaterhaus Jena, the Thuringian Regional Centre for Citizenship Education, the Association of Friends and Sponsors of the Friedrich Schiller University, and last but by no means least, the Southeast Europe Association, Munich.

Rose Ausländer's concept of 'language as a dwelling' turned out to be the inspiration, the leitmotif, that converted our journey to investigate the fading multicultural nature of Romania and western Ukraine into an exhibition for the broader public. Ausländer, born into a German-speaking Jewish family in 1901, is in fact the archetypal figure for the region we were to visit. Her first home was Czernowitz, and her life is an example of how history can change pathways, for Ausländer felt obliged to search for a new, symbolic home when her geographical 'homes' were lost in the political upheavals of the 20th century. ${ }^{4}$ She was born on the outskirts of the Austro-Hungarian Empire, in Europe's most eastern 'German city', which became part of Romania after the First World War. During the Second World War, Czernowitz was occupied by Soviet troops in 1940, but from 1941 to 1944 it belonged to Romania once more. After the war, the Soviet Union took over again and Czernowitz became the capital of the Ukrainian part of Bukovina. By that time the population of the city had changed almost completely, for the ethnic Germans had been deported to Germany in 1944 as part of the national socialist Heim ins Reich policy. After 1945 many ethnic Romanians moved to Romania while most survivors of the Shoah from among the formerly large Jewish community left for Israel, the United States, or Germany. During our field trip we learned that today Czernowitz's history as a city of five languages-German, Yiddish, Ukrainian, Polish and Romanian-is mostly unknown to the town's inhabitants. ${ }^{5}$

In the following we describe our field work in detail, how we created the exhibition, and the events that supported it. We show how our enterprise developed from a romantic (and postmodern) hypothesis into a display of the

\footnotetext{
${ }^{4}$ Rose Ausländer, Gedichte, ed. by Helmut Braun, Frankfurt/M. 2001. Details on Ausländer's life and work can be found at the website of the Rose Ausländer Foundation, http:// www.roseauslaender-stiftung.de/3.html.

${ }^{5}$ For a sound overview of Chernivtsi's multilayered history cf. Helmut Braun, ed, Mythos Czernowitz. Eine Stadt im Spiegel ihrer Nationalitäten, Potsdam 2008.
} 
complexities we found during our empirical cultural-philological and ethnographic research. By presenting the anatomy and outcomes of our collaboration we wish to showcase how interdisciplinary projects in the humanities and social sciences bring forth significant results that can be communicated successfully to a wider public.

\section{Academic Work as a Team. Ethnographic Fieldwork in Romania and Western Ukraine}

We did our fieldwork during two weeks in October 2018, when thirteen students and three lecturers in Cultural Anthropology and Romanian Studies at Jena University travelled from western Romania to western Ukraine. During the preceding summer term, all participants had attended a preparatory seminar and had scheduled meetings with key figures in each of the places they had chosen to visit. Among the interviewees were editors of German-language media, teachers in German schools, protestant priests, archivists, university professors, and writers. However, as our journey began, we added a genuinely Benjaminian empirical approach and turned ourselves into observing flâneurs, starting up conversations en passant and paying close attention to events on the ground. ${ }^{6}$ Equipped with cameras and audio recorders we collected data of all kinds, including in cities and landscapes-everything in fact; human faces and voices, the noises of animals, and the general sights and sounds of all our surroundings. We got lost; we strolled around at random to sense the environment; we familiarized ourselves with the locations and we sketched the bigger pictures of our personal ethnographic encounters when we came together to compare notes at the end of every day. We documented our impressions individually in field diaries, discussed our insights, and protocolled our conversations daily. We developed our method specifically for the team-ethnographic design of our project, and not least, it seemed essential to us to keep hierarchies within the group as flat as possible in order to direct our research towards its consent rather than as an 'exercise-to-be-completed'.

Ethnographers thrive on spending time with people. But how could we do that with such limited time for travelling and within the context of a student seminar? We realized that by deploying team ethnographic methods, we could spread out in different directions-more eyes see more; more ears hear more; more tongues can ask more questions. We were thus able to condense our workload. In a relatively short time and on the basis of rigorous teamled analysis, we gained deep insights and gathered detailed descriptions of

\footnotetext{
${ }^{6}$ Cf. Walter Benjamin, Die Wiederkehr des Flaneurs, in: Michael Opitz, ed, Walter Benjamin. Ein Lesebuch, Frankfurt/M. 1996 (orig. 1929), 471-476.
} 


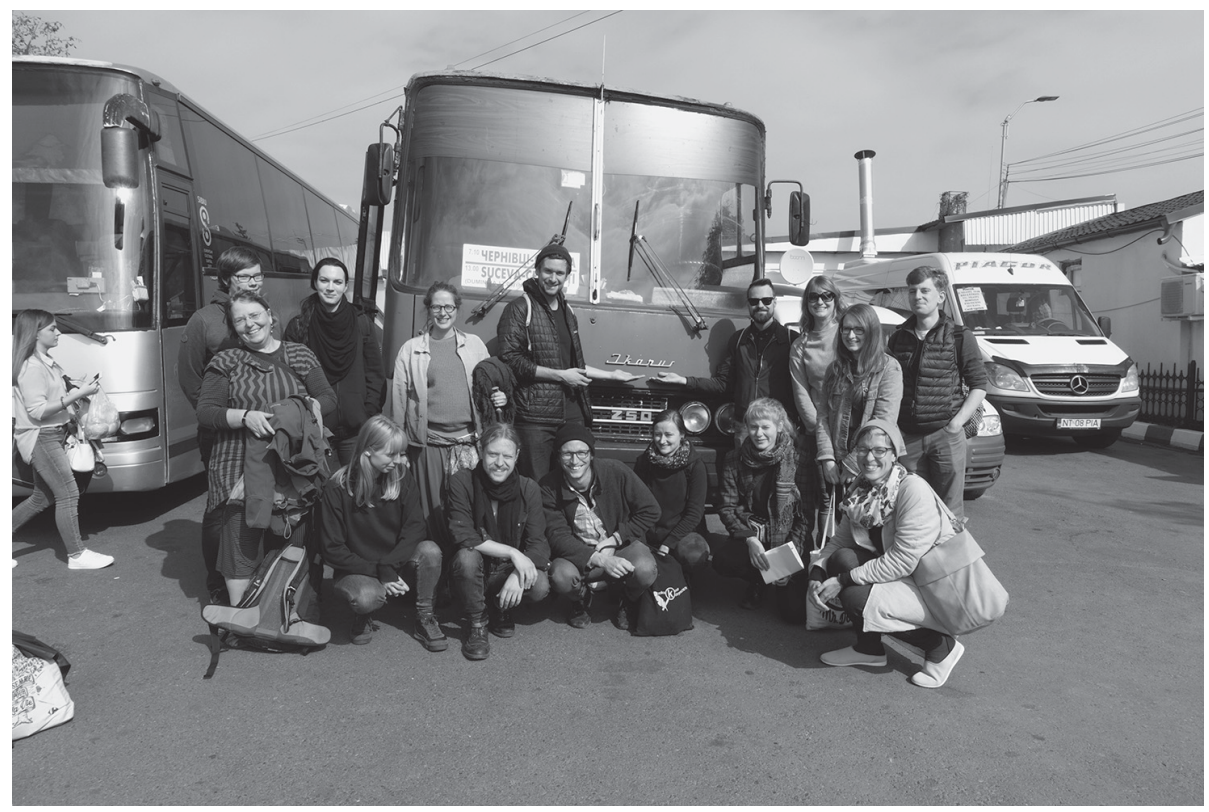

Image 3: The Team in Front of an Ikarus Bus in Suceava before Heading Towards Czernowitz (Courtesy: Anca-Elisabeta Turcu)

how our interlocutors were connected to the complex multicultural whole of their local contexts. ${ }^{7}$ To understand how the German-language communities imagined themselves we tracked historical records and talked to local inhabitants about contemporary matters. Our interdisciplinary group consisted of cultural anthropologists, cultural historians, Romanian philologists and a student of cultural management. We focused on the cultures of Banat Swabians, Transylvanian Saxons, Bukovinian Germans and German-speaking Jewish communities in Transylvania and Bukovina. In both Romania and Ukraine we spoke to people who had lived their whole lives in the region and to others who had emigrated but then come back.

\footnotetext{
${ }^{7}$ Marilyn Strathern, Partial Connections, Walnut Creek/CA 2004 (orig. 1991); Nils Bubandt/Otto Ton, Anthropology and the Predicaments of Holism, in: Nils Bubandt / Otto Ton, eds, Experiments in Holism. Theory and Practice in Contemporary Anthropology, Malden/MA 2010, 1-16; George E. Marcus, Ethnography in/of the World System. The Emergence of Multi-Sited Ethnography, Annual Review of Anthropology 24 (1995), 95-117.
} 


\section{Into the Grey Zone. Making Sense of the Data}

On our return we were confronted by an intimidating pile of data, so much had we and our sixteen pairs of helping hands managed to collect in just two weeks. The biggest challenge was in fact still in front of us, and that was the huge task of communicating our still unprocessed data to a broader public. We had to consider how to address people unfamiliar with the cultural peculiarities of the region, and who could be expected to know especially little of the members of the declining minority communities there. How could we portray effectively the micro-cultures that had developed over centuries in the multicultural landscapes of the Banat, Transylvania and Bukovina? What could we make of their sounds, their objects and dialects, which had been able to develop only in their multilingual communities in contact-and that not always without friction-with each other? Even more, as those communities have appeared actually to be dying out, their rich heritage has come to be revived and remembered in positive ways, such as in occasional folkloric events likes fairs, and national holidays. Meanwhile, the towns and individual houses are nowadays full of interchangeable objects from a delimited cosmos of goods typical for today's globalized world of consumption.

We came to realize that it was not enough to reflect on the traumas of the Romanian and Ukrainian citizens we encountered, the German-speaking ones among them. We felt indebted both to those we interviewed and to those no longer living', and we understood that what we observed 'cannot be disentangled from who we are'. ${ }^{8}$ The memory of the past is untidy. At the microlevel, among people who must live together the lines between good and evil are as blurred as those between cause and effect. In addition, the overlapping of experience in different political contexts has left confused traces which allowed for different answers to the same questions. We therefore embraced the notion of contemporary Eastern Europe as a 'grey zone', because we found it impossible to boil our findings down to any simplified version without omissions which would have been unacceptable. ${ }^{9}$ That 'grey zone' included phenomena that fluctuated between different states, depending on how we looked at them

\footnotetext{
${ }^{8}$ Karen Barad, Nature's Queer Performativity, in: Hildea Romer Christensen, ed., Feminist Materialisms, thematic issue of Kvinder, Køn og forskning / Women, Gender and Research, no. 1-2 (2012), 25-53, 47.

${ }^{9}$ Ida Harboe Knudsen/Marin Demant Frederiksen, Introduction. What is a Grey Zone, and Why is Eastern Europe One?, in: Ida Harboe Knudsen/Marin Demant Frederiksen, eds, Ethnographies of Grey Zones. Relations, Borders and Invisibilities, London 2015, $1-22,1$. The term 'grey zone' was first introduced by Primo Levi in his last book, Primo Levi, The Drowned and the Saved, New York/NY 1988 (Italian original 1986), 36-69. Levi reflects on the actions of the inmates in concentration camps who sought to survive by turning against their fellow inmates, an extremely puzzling behaviour that he tries to explain.
} 
and where we recorded them. They confronted us with moral dilemmas, too. The often-used label 'postsocialist' for the East European societies has tended to overlook their sociocultural complexity, reducing them to mostly economic and political dimensions. Most of our findings in fact could not be traced back exclusively to state socialism, but involved different heritages. What societies in Eastern and Southeastern Europe have experienced since 1989 cannot be labelled simply as something transitory, and in any case developments there have been idiosyncratic and require a sensitive and mindful approach.

We wondered too how to deal with ambiguous statements in interviews, and our own recorded thoughts and feelings, particularly when we felt uncomfortable during the empirical gathering of data. For example, interlocutors repeatedly peppered their remarks with jokes about Roma and bizarre 'biological' theories of cultural evolution, and referred to them using the common local term 'gypsies'. Perhaps unsurprisingly, it was noticeable too that many sought to obscure their parents' or grandparents' involvement with national socialist ideology and practices. More than a few recalled their own pasts using a convoluted mixture of references to the persecution and murder of the region's Jews. In other instances, they did not notice how condescending they sounded when talking of any of their current or former neighbours. That seemed to be especially true in their references to ethnic Romanians.

Soon therefore, our initially romantic idea of a postmodern 'minor model' for an 'inclusive German identity' completely disintegrated. The Southeast European Germans we met demonstrated traditions of culture that had evolved over centuries of living together with other ethnic groups. We came to think of them as based on a separation of monarchist and modernist and the concomitant differentiation. As a result, our search for hybrid identities and co-cultural entanglement turned into an 'anthropology of the dark', a term introduced by cultural anthropologist Sherry Ortner to draw attention to how neoliberalism and globalization have provoked an anthropology on 'all the bad things happening' in most societies since the mid-1980s. ${ }^{10}$ Even although we could indeed trace many of our findings to the nowadays overwhelmingly economically shaped modes of consumption and capitalist ethics in everyday life orientations, we use the term in a broader sense too of 'a trend in anthropology to pay attention to "people we don't (necessarily) like"'.11

Our German interlocutors seemed to be scarred by history, and many turned complex entanglements between historical and contemporary cultural experiences into simple 'truths'. For example, they harboured a deep mis-

\footnotetext{
${ }^{10}$ Sherry B. Ortner, Dark Anthropology and Its Others. Theory Since the Eighties, Journal of Ethnographic Theory 6, no. 1 (2016), 47-73, DOI: 10.14318/hau6.1.004.

${ }_{11}$ Sindre Bangstad, Doing Anthropology Among People We Don't (Necessarily) Like, Anthropology News, 28 August 2017, https://doi.org/10.1111/AN.584, 1.
} 
trust of any media statement about current political affairs. Our interviewees were more concerned with what they perceived to be the present condition of the German nation state than with the Romanian state. For example, the so-called 'refugee crisis' of 2015 was a source of especial concern and imagined conspiracy. Many people we talked to, of various cultural and ethnic backgrounds, believed individuals such as Russian president Vladimir Putin or the American entrepreneur George Soros to be key actors in Europe's political affairs. Some even raked up the Morgenthau Plan at the end of the Second World War, which envisioned Germany as a powerless agrarian state in order to prevent it from ever again launching an aggressive war. The link to current politics was the hypothesis that the refugee crisis of 2015 was part of a greater plan to 'destroy the German people' by overthrowing German culture by means of Islamization. One woman warned us that 'three generations from now, you will not exist anymore. You underestimate Islam, you will be all Muslims.'

We were dismayed by such conspiracy theories and engaged in discussions about what we perceived to be the strength of grown traditions, refusing to accept any assumption of any 'eliminatory anti-Germanism' at work. To us, our interlocutors seemed the product of postimperial and socialist Romanian political culture. Many expressed deep mistrust of German attempts to 'integrate' the most recent refugees into the majoritarian cultural system. In congruence with this we came to understand that their own collective experience of living in Romania with neighbours of other ethnic, linguistic and religious origin was not seen by them as a reservoir of positively connoted togetherness. On the one hand they were Romanian Germans. 'In Romania,' they said, 'you can only be a Transylvanian German.' On the other hand they were members of a persecuted, expropriated, even sold minority who happened to have been seduced by national socialism. And there we saw the link that made them see Germany's challenges in the globalized post-9/11 world through conspiratorial eyes. Romanian Germans believe Germany needs to protect its identity in much the same way as they, the Romanian Germans, have been forced-or believe they have been forced-to protect their own collective identity over the centuries among other peoples.

We found out later that the conspiracy theories our interviewees referred to are popular in 'alt-right', nationalist and patriotic circles in Romania. We concluded that such theories resonated with German Romanians because they linked them to their own experiences of persecution in the aftermath of the Second World War, when many adult members of the German minorities in Romania were deported to forced labour camps in the Soviet Union, and when most expropriations from German families occurred. In addition, experiences of mass surveillance in socialist Romania seem to have contributed to the pre- 
vailing mistrust of politics and the media's communication of history. Older interlocutors quite openly admitted to us their formerly everyday activity as informants for the Romanian socialist secret service, the Securitate. The majority we spoke to imagined that the 'true story' is never told to 'the people'. At some point we even began to feel controlled ourselves by the key figures we interviewed. The more deeply we became entangled with our field, the more suspicious we became. We began to wonder who had known we were coming and where we should be stopping off on of our journey? Eventually then, our 'grey zone trip' among the fading presence of Germans in Romania began to affect the way we ourselves looked at things. Only when we were back in Germany, poring over the transcribed interviews in the safe space of our own seminar room, could we see that we had experienced the same superpositions of vision that Primo Levi had realised. In describing the 'grey zone', Levi had been able to explain how it showed 'an incredibly complicated internal structure' and that it contained 'within itself enough to confuse our need to judge'. ${ }^{2}$

Back at the Friedrich Schiller University we had to develop a concept that would enable us to translate our findings into something a larger audience could understand. Again, time was short. Forced into a seminar format, we knew that because our goal was to open the exhibition within six months, many hours of frantic work lay before us. There were the still un-transcribed interviews, the yet-to-be-decoded field notes and the film and sound sequences we still had to cut together, all to be done as quickly as possible. Hundreds of photographs as well as pages and pages of field diaries and protocols of the plenary sessions had to be analysed and placed in some sort of order. Our collective ethnographic effort and the unorthodox didactic design of the project were based on balanced use of digital media applications and analogue modes of togetherness and sharing. To that end we worked in small groups with regular collective meetings. We applied the concept of a 'seamless digital space' to make our infrastructures interact better, thereby going beyond the usual dimensions of students' project work. ${ }^{13}$ The use of messenger apps, digital workspaces, communication hubs, and online repositories for large data sets created a virtual space that meant we could master our extensive programme despite the time constraints. Similarly, the results from the subgroups could be integrated into the larger context. Indeed, our most committed students worked intensively over a number of weeks during which was forged a genuine team spirit that allowed the whole group to test its limits, and even extend them.

\footnotetext{
${ }_{12}$ Levi, The Drowned and the Saved, 42.

${ }^{13}$ Janet Vertesi, Seamful Spaces. Heterogeneous Infrastructures in Interaction, Science, Technology and Human Values 39, no. 2 (2014), 264-284, DOI: 10.1177/0162243913516012.
} 


\section{Visualizing 'Ethnograffiti'}

Analysing our data, we found ourselves being challenged to decide how we could exhibit historical conditions and contemporary circumstances of minority and multiethnic common sense as well as everyday experience, from eating, praying, dancing and celebrating to casting votes and leading conversations. Rose Ausländer's metaphor of 'living door to door', or rather 'word to word', showed us the solution, so that architectural metaphors and concepts of dwelling became the basis on which we sorted the material. These then are the titles we decided on for the seven stations of the exhibition: 'All under One Roof' (Alle unter einem Dach); 'Floor Plans of Others' (Grundrisse der Anderen); 'Debris, Dreams, Traumas' (Trümmer, Träume, Traumata); 'Behind Closed Doors' (Hinter verschlossenen Türen); 'New Landlords since 1989' (Neue Hausherren seit 1989); 'Ramshackle Ruins' (Verwohnte Ruinen); and 'Signpost Team-Ethnography' (Wegweiser Teamethnografie).

Apart from conveying our findings, we had to provide a general introduction to the regions we visited. The Germans of Southeastern Europe identify strongly with the German state. However, the Banat, Transylvania and Bukovina and their German history represent rather a blind spot for large sections of the local public in Thuringia. Our 'dark' experiences within the 'grey zone', the entanglements between the visions of the ethnographic field and the ethnographers themselves, were therefore only one section of the larger picture we were offering the audience. In the wake of the 30th anniversary of the East European revolutions of 1989, our data allowed us to draw special attention to how the mechanisms of silencing, surveillance, and censorship existing under state socialism have influenced patterns of communication in the postsocialist societies. That larger picture allowed us to embed our exhibition and the supporting events in the framework of Jena's 30th anniversary programme entitled, '89//19: Loss Upheaval - New Departure. Jena and the Revolution(s) of 1989'. ${ }^{14}$

We wove the individual accounts of our interlocutors into our own historical contextualisation and what our biographical research told us, a useful adjunct to our more theoretical debates on ethics, discourse analysis and cultural theory. At one point we decided we should stop trying to come to terms with our data's incoherence, instead choosing to reflect it back to the exhibition's visitors. We felt that we could thereby share the work of making sense of these complex fields and their contradictory implications. We focused on fragments, snapshots, and sound scenes to display a multicultural landscape. In fact what we were doing was sketching 'ethnograffiti', a term we came up with ourselves during our data analysis. Not the least of the term's value was that it

${ }_{14}$ 89//19 - Weg/Um/Aufbruch. Jena und die Revolution(en) von 1989, Jena 2019, https:// www.jenakultur.de/fm/2316/Programmbroschüre_89-19.367044.pdf, 44-46. 
helped us show as part of the exhibition how the ethnographic method is in fact a process.

However, we went to some trouble to make sure the exhibition would reflect both sides of the story, with our own original hypotheses, our unforeseen findings, and our interpretations. In each section, an enlargement of an atmospheric photograph taken on our journey by a member of the team is accompanied by a literary quotation, both giving a general idea of the section's topic but also creating a reflexive environment while visitors listen to the interviewees' own remarks and

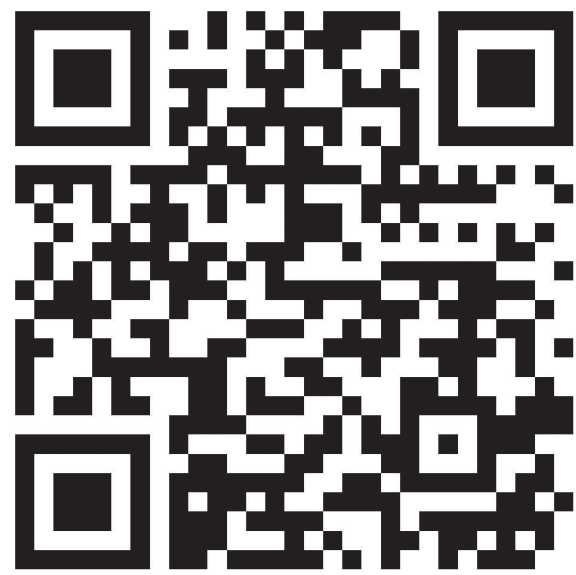

Image 4: Sound Collage Created for the Exhibition (by Elisabeth Knoblich) look at the objects displayed. The various multimedia installations, each station containing direct quotations from audio sources, range from interviews to music and street noises. They give an insight into the spoken and heard worlds of our ethnographic project, as do the photographs and film sequences visually.

The first section, 'All Under One Roof', presents interviewees' positive references about living in a multicultural world, and their explanations of how and why it worked. 'Floor Plans of Others', the second station, talks about how members of one ethnic group described members of another in terms of distinction, but not necessarily negatively. The third stop, 'Debris, Dreams, Traumas', presents quotations that reflect the manifold traumas, disappointments and frustrations of the Germans and Jews in Romania during the 20th century, including their degradation to 'non-Romanians' in the newly emerged enlarged Romania in 1918; the Nazism embraced by the ethnic Germans (Volksgruppe) in the interwar years; and the submerged memory of the Shoah. As already touched upon, Germans in socialist Romania felt themselves generally suspected of Nazi sympathies and faced deportation to the Soviet Union or labour camps within the Romanian state. Eventually, Germans and Jews were 'sold' to Germany and Israel respectively, and ultimately almost all of them emigrated after 1989. The migration processes resulted in profound upset both for those who left and for those who remained.

The exhibition's fourth part, 'Behind Closed Doors', gives an insight into what living in state socialist Romania was like, with its ever-present threat of denunciation in a society so deeply infiltrated by agents of the Securitate secret service. 'New Landlords since 1989', station number five, addresses our interviewees' experience of being 'replaced' after leaving the country, that is 


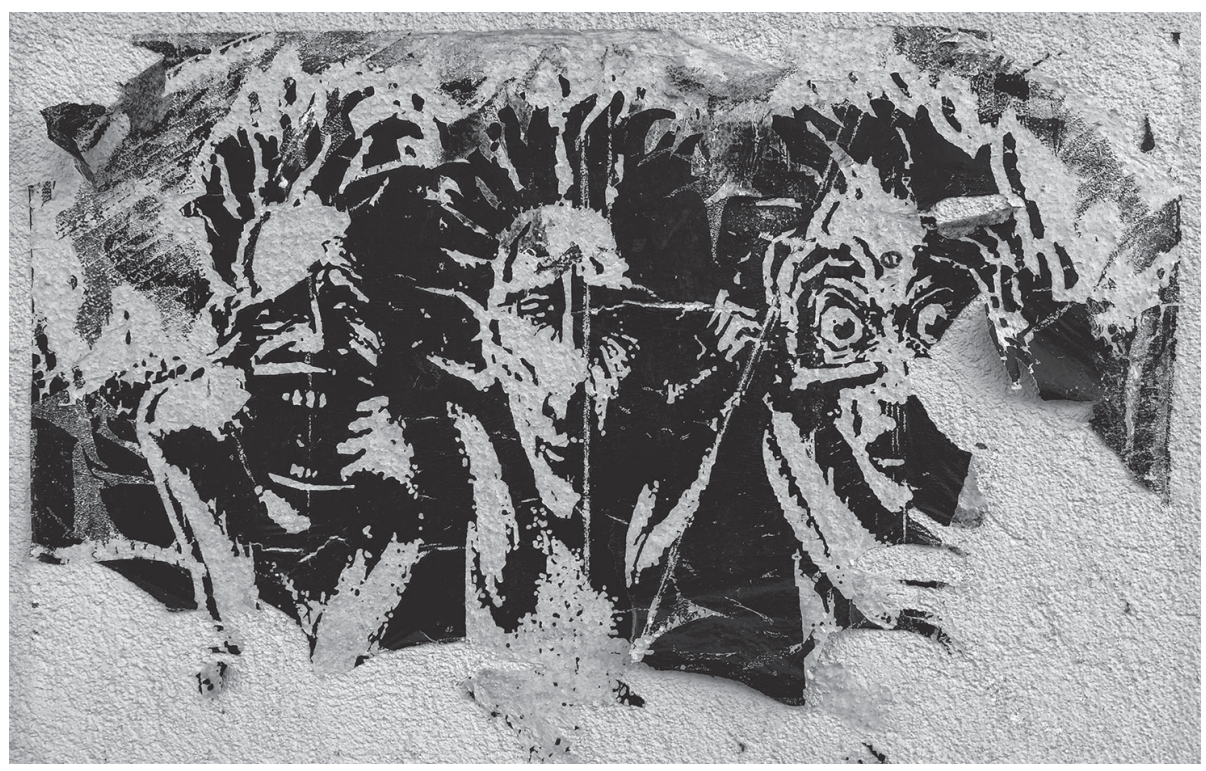

Image 5: Photograph for the Station 'Behind closed Doors' (Courtesy: Anne Dippel)

watching new inhabitants moving into the homes they had left behind, or ethnic Romanian children attending German schools and folk dance groups. The sixth locus, 'Ramshackle Ruins', takes up the disappointment of those who continue to live in Romania and have witnessed the decay of cultural heritage architecture and buildings in general. The seventh and final post, 'Signpost Team-Ethnography', is dedicated to the story of our own trip, exhibiting our methodology and how we organized our team ethnography. Visitors may choose to read either the protocols of our plenary sessions during the journey, the much fuller descriptions written by members of our research team, a collage of excerpts from the field diaries, or the sound and video installations compiled by some of the students. Our overall aim is to allow visitors to participate in the cognitive process and to make our research comprehensible, even with all its uncertainties and remaining questions.

Taken together, the 'ethnograffiti' in all these thematic sections amount to an 'ethnographic riddle'. Acknowledging that what we can comprehend are only partial connections in more complex wholes which will always retain moments of interpretive uncertainty, we decided to take seriously Hegel's maxim that the 'riddles of the ancient Egyptians were riddles also to the Egyptians themselves'. ${ }^{15}$ Slavoj Žižek, adding to Hegel, argues that it is impossible

${ }^{15}$ Georg Wilhelm Friedrich Hegel, Die Religion des Rätsels, in: Georg Wilhelm Friedrich Hegel, Vorlesungen über die Philosophie der Religion I, Werke, vol. 16, Frankfurt/M. 1969, 


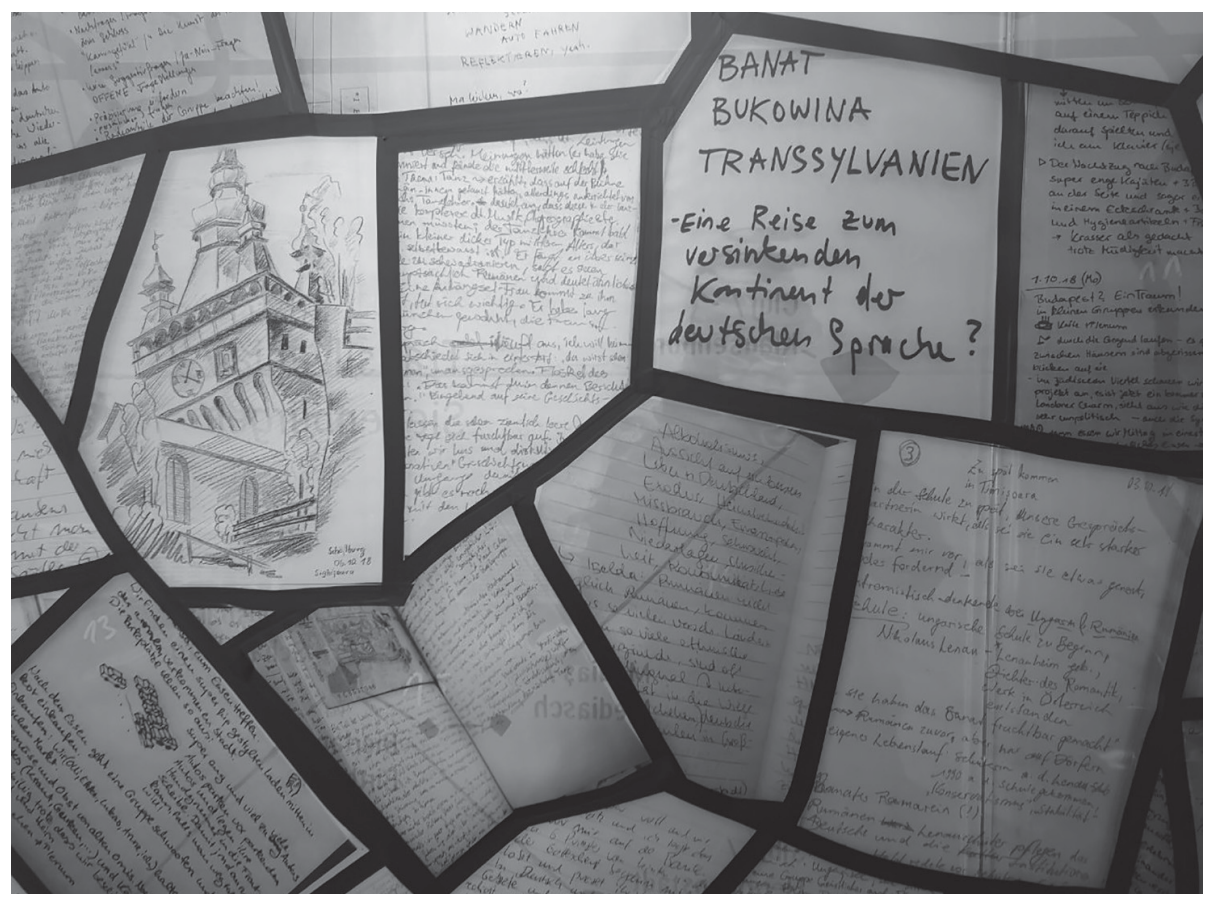

Image 6: Field Diaries on Display (Courtesy: Lukas Davids)

to develop any understanding of an ethnographic field if the ethnographer fails to find a culture's 'enigmatic spot' when meeting interlocutors, which is to say their own astonishment about any empirical phenomenon. That is why in our exhibition we explain how we as ethnographers feel a distance from the traditions, customs, everyday practices, and convictions. ${ }^{16}$ Consequently, the objects exhibited in 'Word to Word' are meant to be understood as mere hints-however multidimensional-at what we brought back from our field trip to Romania and Ukraine. Wort an Wort documents how a mindful collective ethnography contributes to making sense of the transformation of a multicultural European society. As part of a metadialogue within various disciplines of the humanities and social sciences on how to 'go public', we chose to use our exhibition to reveal the cognitive process that is part of any research activity.

409-442, 435. Cf. Anne Dippel, Dichten und Denken in Österreich. Eine literarische Ethnographie, Vienna 2015, 16.

${ }_{16}$ Slavoj Žižek, Das rassistische Schibboleth, fair. Magazin für Kunst und Architektur 11 (2010), E7. Cf. Dippel, Dichten und Denken, 17. 


\section{Sunflower Seeds as a Challenge, and Other Supporting Events}

The exhibition was supported by a number of public events. At the private showing, one of the exhibited objects served to illustrate contrary metaphors. That object was a packet of sunflower seeds. To explain their presence, journalist and author Marius Koity, originally from the Banat but now based in Gera in Thuringia, read one of his poems. The verses play with the image of the popular Balkan pastime of gorging on sunflower seeds, the shells piling up on the floor like sand through an hourglass to reflect the slow rhythm of time. However, in his poem Bericht eines, der auszog (Poem of one who set forth) written in 1987, Koity instead applies the well-known image to political parvenus; he has them spitting the sunflower shells into each other's eyes. ${ }^{17}$ When still living in Romania, Koity was accused of being a German nationalist hostile to the Romanian state and therefore suspect in the view of the Securitate. His use of the bucolic image of sunflower seeds was therefore in sharp contrast to his politically astute poetry.

Another event in support of our exhibition was the presentation-in Friedrich Schiller's Garden House-of Annemarie Otten's graphic novel Elternerde (Parents' Soil). The Garden House, incidentally, is the only house remaining from Schiller's years in Jena, and is today part of the university. ${ }^{18}$ An expert in communications design, Otten tells the story of her ancestors between the end of the Second World War and the 1980s. Their trajectory included deportation and finally emigration from Romania. Even though Otten was raised in Germany and so has little first hand insight, she reproduces the negative statements she heard from her grandmother about the 'other' ethnic group, the Romanians, and about Romania itself. In general terms she confirms research findings that have demonstrated how relatively uncritical is the transmission of experience between grandparents and grandchildren. ${ }^{19}$ In Otten's case more concretely, the story illustrates the commonly told story of the Germans in 20th century Romania. This narrative is solely of suffering-and therefore hiding those particular Germans' involvement both in national socialism and with the subsequent communist authorities. In the story of Otten's grandmother, the older woman's deep mistrust of and disappointment with the Romanian state and Romanians in general take centre stage. Later, those feelings are evoked to explain why Germans left the country en masse in the last quarter of the 20th century. Otten's graphic novel therefore fits extremely well

\footnotetext{
${ }^{17}$ Marius Koity, Eine unvermeidliche Collage. Gedichte, meine alten Tagebücher und andere Papiere, Ludwigsburg 2016, 15.

18 Annemarie Otten, Elternerde, Munich 2014.

19 Harald Welzer/Sabine Moller / Karoline Tschuggnall, eds, 'Opa war kein Nazi.' Nationalsozialismus und Holocaust im Familiengedächtnis, Frankfurt/M. 2003.
} 
with various parts of our exhibition, especially 'Floor Plan of Others', 'Debris, Dreams, Traumas' and 'Behind Closed Doors'.

In a further supporting event, this time at the Café Wagner, another of Jena's local institutions, novelist Carmen-Francesca Banciu read from her novel, 'A Land Full of Heroes'. The work is a condensed collage of different perspectives among a circle of friends who reflect on the Romanian revolution of 1989. Set in the immediate aftermath of those events, the novel shows the group's feelings of disorientation, their questioning of their relationships and their sense of betrayal and loss. ${ }^{20}$

Again at the Café Wagner, the students organised a performative reading of US cultural anthropologist Katherine Verdery's award winning book, My Life as a Spy, taking the audience back to the era of the 1970s, behind the Iron Curtain, when Verdery did her first fieldwork in Romania. ${ }^{21}$ During the 2000s Verdery had the opportunity to study her Securitate file, and she contrasts her field notes from that period with the Securitate reports and the observations made by the friends who accompanied her-and partly spied on her. Her reflections on the nature of anthropological research are highly instructive. Given that anthropological research is about observing people, Verdery points out that at least from the appearance of the means applied, there are many aspects of it that are oddly similar to spying.

In another public reading, at Café Bauersfeld, Iris Wolff read from her book Halber Stein (Half a Stone). The book, clearly to some extent autobiographical, is about the rediscovery of Transylvania by a young German who returns to the romantic idyll of the village where she was born but which she left as a child when her family moved to Germany. ${ }^{22}$ The village has been almost emptied of its German inhabitants, but as the story proceeds her family meets there for the funeral of the main protagonist's grandmother. There ensues dispute over their reasons for leaving the country. Wolff explained how her generation, with little or no experience of living in Romania, harbours nostalgic memories, while their parents' and grandparents' generation retain severe reservations about the Romanian state and prefer to avoid looking back.

At the Kulturbahnhof Jena cultural centre the Berlin-based Austrian writer and artist Sissi Tax staged a performative reading of texts both of her own and by Adolf J. Storfer and Rose Ausländer. In a dialogue with Anne Dippel that was both intellectual and satirical, she vividly brought to mind the cultural charisma of the Bukovina of yore, setting its culture in its former Austrian

\footnotetext{
${ }^{20}$ Carmen-Francesca Banciu, Ein Land voller Helden, Berlin 2019. The novel appeared first in Romanian in 1998, the German translation in 2000.

${ }^{21}$ Katherine Verdery, My Life As a Spy. Investigations in a Secret Police File, Durham/NC 2018.

${ }^{22}$ Iris Wolff, Halber Stein, Salzburg 2012.
} 
imperial context. And, as the final although certainly not the least part of the cultural programme supporting our exhibition there were musicians too, such as the young pianist Teodora Oprișor, the band La Bassarabia Banda from Leipzig, and the Jena-based DJ Illmagic. All the artists, literary and musical, added to communicating the region's charm through their play with sounds and semantics.

We also organized a panel discussion on the politics of memory. We called it 'Irrevocably Abandoned and Estranged? German and Jewish Life in Museums of Romania and Southern Ukraine after 1989' (Endgültig verlassen und entfremdet? Zur Musealisierung deutschen und jüdischen Lebens in Rumänien und der südlichen Ukraine nach 1989). We were interested in hearing what architecture and monuments the panellists thought could be preserved, and what forms of cultural life they saw as existing and could be sustained in spite of the fact that most Germans and nearly all Jews had vanished from the region. Cornelia Eisler of the Federal Institute for the Culture and History of the Germans in Eastern Europe, Oldenburg, Florian Kührer-Wielach of the Institute for German Culture and History in Southeastern Europe at the Ludwig Maximilian University Munich, Oxana Matiychuk of the Gedankendach Center and University of Chernivtsi and Michaela Nowotnick of the Arno Schmidt Foundation, Bargfeld, showed a deal of optimism in their discussion of recent archival activities, museums, and cultural events in Romania and Ukraine. They pointed out how the German and Jewish heritage has been appreciated in the region, and the importance of the fact that young people tend to respond positively to these cultural offers, and comment creatively on them.

A particular highlight of the supporting programme was the guest performance of the play 'Romanian Diary. Timișoara' by theatre and film director Carmen Lidia Vidu. On the way to Romania our group had visited the German State Theatre in Timișoara and had been guests at the dress rehearsal of the play. Deeply touched by it, we decided to invite the ensemble to Jena, which meant a number of students becoming extremely busy writing letters to various institutions in Thuringia. Fortunately, they succeeded in securing the financial support of Jena's municipal theatre, the Theaterhaus, and of the city of Jena. We were therefore able to invite the company of six actresses, two technicians, their assistant director and the playwright, Carmen Lidia Vidu herself. Indeed the Theaterhaus, most aptly, added the play to its festival programme 'Voice of Europe'. The play's all-women cast presented their personal histories in socialist Romania, and their lives since. ${ }^{23}$ They shared straight-talking and sometimes disturbingly frank observations about their immediate environ-

${ }^{23}$ For a description of the play 'Tagebuch Rumänien. Temeswar' cf. the website of the German theatre in Timișoara, https://www.deutschestheater.ro/de/spectacole/jurnal-derom\%C3\%A2nia-timi\%C $8 \% 99$ oara/. 


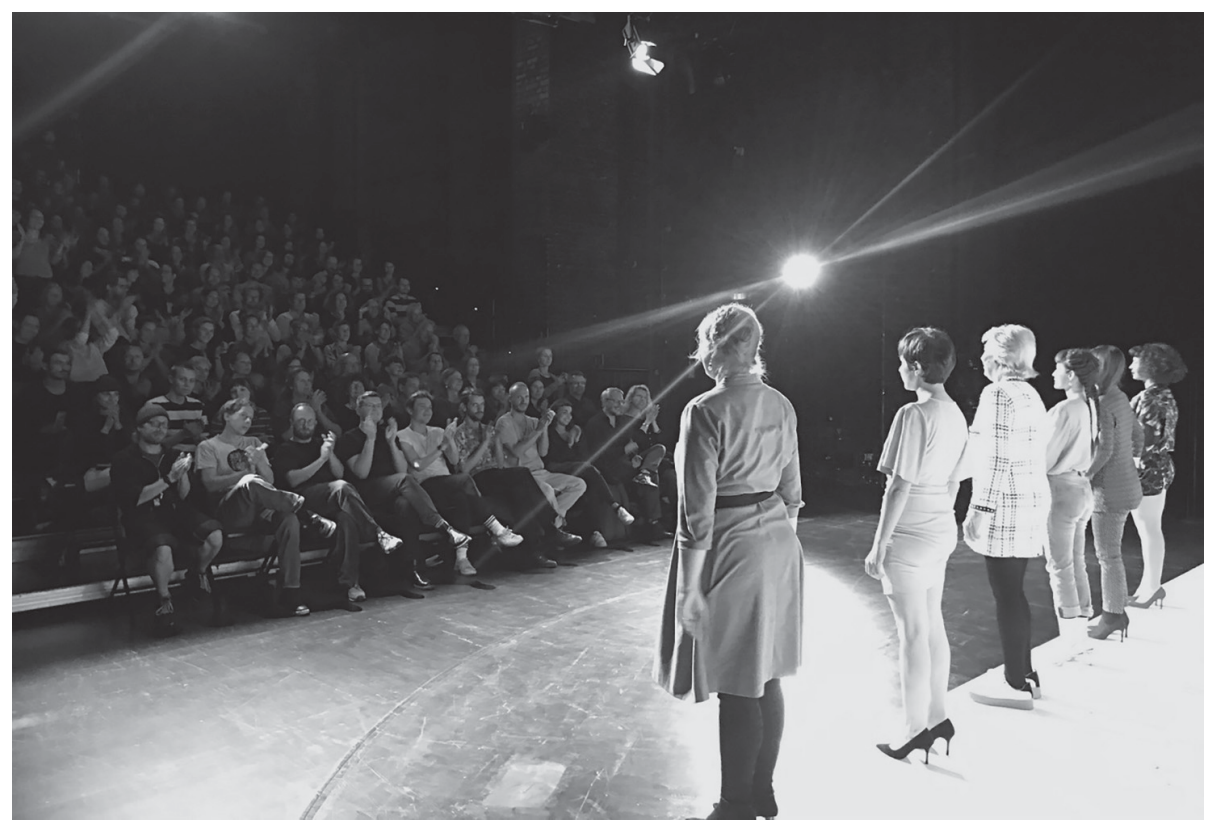

Image 7: The Ensemble of the German State Theatre Temeswar on Stage at the Theaterhaus Jena (Courtesy: Carmen Lidia Vidu)

ment, giving intimate insights into Romanian society, its imperfections and profound malaises from a female perspective. Vidu expressly intends her 'Romanian Diary' to be a means to enhance communication about Romanian society, and yet in the last scene one of the actresses sings Depeche Mode's 'Enjoy the Silence', which depicts words as essentially painful ('Words are very unnecessary; they can only do harm...'). After the performance, Carmen Vidu and her team entered into an intense discussion with the audience. In what turned into a two-hour exchange, Vidu explained how it was anthropology that had inspired her work with the actresses and indeed her realization of the play as a whole. Her words really meant our interdisciplinary endeavour had come full circle, for her play crystallized our project's aim of moving between the extremes of trauma and nostalgia, and of linking them to our main question about the possibilities and limits of living together for diverse people.

\section{Conclusion}

In our project we focused on the performative aspects of engaging with diverse cultures for a wider public while promoting a mindful approach to self-reflective ethnography. In exhibiting the fading multicultural formation 
of present-day Romania and the history of German and Jewish culture in the Banat, Transylvania and Bukovina, we resolved to understand each word and each performed image as a shibboleth. We staged the fleeting nature of words, noting their semantic ambiguity as it is related to cultural time and historical space. Words are signifiers that distinguish one group from another, be it by self-identification, by signalling loyalty or affinity, or by carrying a segregating or self-protective content. ${ }^{24}$

The exhibition reveals how ethnographic fragments weave a web of partial connections, which make up a complex whole constituted both by our exhibitory effort and the receptive input of the visitors. It is inspired by an aesthetic of reception as first articulated by Bertolt Brecht for the theatre and later refined by Harun Farocki for film. ${ }^{25}$ It is an aesthetic designed to encourage viewers to draw their own conclusions rather than presenting them with prefabricated answers for their passive consumption. Using this technique we showcased the importance of the Humanities and Social Sciences and fulfilled our duty to make them public. Making an exhibition means creating an environment that is at once intellectually stimulating and sensually seductive. Exhibiting everyday life, art and literature as being entangled with each other challenges the image that the Humanities and Social Sciences cultivate their disciplines in the proverbial 'ivory towers'. In today's academic landscape scholars interested in some particular topic often build interdisciplinary bridges to master complexity, as we did when we decided to combine elements of Cultural Anthropology and Romanian Studies. At a time when political horizons are narrowing and nationalist ideologies re-emerging, Wort an Wort takes words outside scholarly cloisters to bring to a wider public messages about cultural complexity as something familiar and common; and not as a frightening thing, but as something stimulating. For our part, our emphasis on the hybridity of sociocultural phenomena, and our revealing how data is made flesh within the ethnographic process, amount to taking ethical and political action. In our plea for a public anthropology and philology, we have taken words into action.

\section{CORRESPONDING AUTHORS}

Valeska Bopp-Filimonov Friedrich-Schiller-Universität, Institut für Romanistik, Ernst-Abbe-Platz 8, 07743 Jena, Germany. E-mail: valeska.bopp-filimonov@uni-jena.de

Anne Dippel Friedrich-Schiller-Universität, Seminar für Volkskunde (Empirische Kulturwissenschaft) / Kulturgeschichte, Zwätzengasse 3, 07743 Jena, Germany. E-mail: anne.dippel@uni-jena.de

\footnotetext{
${ }^{24}$ Jacques Derrida, Shibboleth. Für Paul Celan, Vienna ${ }^{3} 2002$.

${ }^{25}$ Bertolt Brecht, Schriften zum Theater. Über eine nicht-aristotelische Dramatik, Frankfurt/M. 1999; Tilman Baumgärtel, Vom Guerillakino zum Essayfilm. Harun Farocki, Berlin 1998.
} 